Original Article

http://dx.doi.org/10.1590/0104-07072014001560013

\title{
INVESTIGATION OF MEDICATION ADMINISTRATION THROUGH CATHETERS IN INTENSIVE CARE
}

\author{
Carolina de Deus Lisboa1, Lolita Dopico da Silva², Guacira Corrêa de Matos ${ }^{3}$
}

\footnotetext{
${ }^{1}$ M.Sc. in Nursing. Intensive Care Unit Nurse, Rio de Janeiro, RJ. Rio de Janeiro, Brazil. E-mail: lisboa.carol@gmail.com

${ }^{2}$ Ph.D. in Nursing. Professor, Graduate Nursing Program at Universidade do Estado do Rio de Janeiro. Rio de Janeiro, Rio de Janeiro, Brazil. E-mail: lolita.dopico@gmail.com

${ }^{3}$ Ph.D. in Public Health. Professor, Medication Department, School of Pharmacy at Universidade Federal do Rio de Janeiro. Rio de Janeiro, Brazil. E-mail: gcmatos@globo.com
}

\begin{abstract}
This study aims to identify errors in medication administration through probes and characterize the interruption or not of nutrition in the case of drugs that require relative fasting. This is an epidemiological, cross-sectional and observational study in intensive care with a sample of 350 doses of drugs administered by 56 nursing technicians. The results showed no pause between the drug administration and the infusion of enteral feeding in 116 (33.14\%) doses of drugs that required relative fasting, including captopril, sodic warfarin, sodic levothyroxine, sodic digoxin and sodic phenytoin. The irrigation of probes did not occur (94.28\%) in most cases. It is concluded that the serum bioavailability of the drugs mentioned may have been reduced, compromising their therapeutic efficacy; and that the lack of probe irrigation with sterile water before administering drugs shows the absence of a specific and fundamental care to prevent probe clogging.
\end{abstract}

DESCRIPTORS: Medication error. Nursing. Security measures.

\section{INVESTIGAÇÃO DA ADMINISTRAÇÃO DE MEDICAMENTOS POR CATETERES EM TERAPIA INTENSIVA}

\begin{abstract}
RESUMO: Pesquisa com os objetivos de identificar falhas na administração de medicamentos por sondas e caracterizar a interrupção ou não da nutrição no caso de medicamentos que exigem jejum relativo. Estudo epidemiológico, transversal, observacional numa terapia intensiva, com amostra de 350 doses administradas por 56 técnicos de enfermagem. Os resultados mostraram que não houve pausa entre a administração do medicamento e a infusão de dieta enteral em $116(33,14 \%)$ doses de medicamentos que necessitavam de jejum relativo, entre os quais captopril, varfarina sódica, levotiroxina sódica, digoxina e fenitoína sódica. A irrigação das sondas não ocorreu na maioria dos casos $(94,28 \%)$. Conclui-se que é possível que os medicamentos citados tenham tido sua biodisponibilidade sérica reduzida, comprometendo sua eficácia terapêutica e que a falta da prática de irrigar sondas com água estéril, antes de administrar medicamentos, configura-se como a ausência de um cuidado específico fundamental para evitar a obstrução das mesmas.
\end{abstract}

DESCRITORES: Medicamentos. Enfermagem. Nutrição enteral.

\section{INVESTIGACIÓN DE LA TÉCNICA DE ADMINISTRACIÓN DE MEDICACIONES POR CATETERES EN TERAPIA INTENSIVA}

\begin{abstract}
RESUMEN: Estudio con objetivos de identificar errores en el manejo de catéteres y evaluar la interrupción de la dieta durante medicaciones que exijan ayuno. Investigación transversal, observacional en terapia intensiva. Se observaron 350 dosis administradas por 56 técnicos de enfermería. Los resultados muestran que no hubo pausa entre la administración del fármaco y la infusión de dieta enteral en 116 dosis $(33,14 \%)$ que necesitaban de ayuno relativo, como el captopril, varfarina sódica, levotiroxina sódica, digoxina y fenitoína sódica. Con relación a la irrigación de los catéteres, esta no ocurrió en la mayoría de los casos (94,28\%) antes de la administración del medicamento. Se concluye que es posible que los fármacos citados hayan presentado su biodisponibilidad sérica reducida, comprometiendo su eficacia terapéutica y que la falta de prática de irrigar catéteres con agua estéril antes de administrar los medicamentos, se caracteriza como la falta de un cuidado específico fundamental para evitar la obstrucción de los mismos.
\end{abstract}

DESCRIPTORES: Medicaciones. Enfermería. Nutrición enteral. 


\section{INTRODUCTION}

At Intensive Care Units, many patients receive Enteral Nutrition (EN) through gastrointestinal catheters. Enteral nutrition therapy is defined as special-purpose food, with controlled nutrient intake, in an isolated or combined form, with a defined or estimated composition, especially formulated and elaborated for use through catheters or orally, industrialized or not, used exclusive or partially to replace or complement oral feeding in patients who are malnourished or not, according to their nutritional needs, whether under an hospital, outpatient or home-care regimen, aiming for the synthesis or maintenance of tissues, organs or systems. ${ }^{1-2}$

Patients on EN through catheters frequently also receive medication through this route. This practice may entail different consequences, two of which are closely related with nursing care, which are luminal obstruction of the catheters and drug-nutrient interaction. In that sense, it should be reminded that solid drug administration remains frequent and that the technique for its administration through catheters basically involves grinding pills or opening capsules and dissolving the content in water for further administration. The bad dispersion of pills or capsules in water can cause the obstruction of the probes when the drug adheres to the catheter wall, especially when the pills have some kind of coating or when the capsules contain some kind of granule instead of powder. ${ }^{3}$

It is estimated that the best way to avoid obstruction is the use of liquid forms of the drugs, such as solution, suspension or magistral formulae. The obstruction can lead to the need to change the probe, increased work for nursing, worse quality of patient care, loss of medication administration, reduction of nutrient intake, increased cost and increased patient anxiety. ${ }^{3-4}$

As mentioned earlier, another important consequence of medication administration through tubes is the drug interaction with nutrients, mainly proteins. In recent years, studies focused on medication administration through tubes have been published, focusing on the interaction between the drug and EN. ${ }^{5-6}$

It is known that the infusion of EN can affect the bioavailability of the drug due to interactions between nutrients and drugs. If the bioavailability is affected, both the pharmacodynamics and therapeutics will change. Therefore, it is fundamental to know the active substances in each drug and whether the presence of the nutrient affects its absorption speed or not. The delayed absorption of some drugs, when consumed with EN, does not always indicate a reduction of the quantity absorbed. But a longer period will probably be necessary to reach its maximum blood concentration, interfering in the latency of the effect. In view of the infusion speed of enteral diets and of gastric emptying (for topographical probes in the stomach), in general, a 30-minute pause is recommended between the enteral diet and medication administration. ${ }^{4-5,7}$

Therefore, when administering medication through tubes, it is important to consider whether the tube is irrigated or not before, in between and after the medication administration and what drugs require a pause in the diet. Some studies indicate that administering medication without analyzing the impact of these variables can cause a reduction in the therapeutic effect and possible patient damage..$^{8-9}$

In this study, the objectives were centered on only two aspects of drug administration through tubes: the errors committed in tube handling and the absence of a pause for drugs that require relative fasting.

Various other factors can cause errors, such as ignoring the dietary composition, its administration method and ignoring the influencing of the tube location in the patient on the absorption process of nutrients and drugs. Nevertheless, studies are needed that are only focused on specific nursing actions, such as tube management during medication administration or observing a pause for certain drugs. ${ }^{3-4}$

The contribution of this publication is based on the possibility of helping to guide strategies that cooperate towards safe medication administration through catheters, as it investigates variables that need to be assessed to estimate their impact on safe medication use and what can be done to reduce errors in medication administration through tubes.

\section{METHOD}

An observational research with a crosssectional design was undertaken at the ICU of a large private hospital located in Rio de Janeiro. The observation was based on two categories of administration errors; the first related to the pause in the enteral diet, and the second to the catheter 
handling. An error in the "pause" category was considered when there was no 30-minute interval between the interruption of the EN and the administration of drugs requiring relative fasting. An error in "catheter management" was considered when the catheter was not irrigated with at least $10 \mathrm{ml}$ of sterile water before the administration, in between drugs and after the medication administration. The use of sterile water was considered compulsory, in compliance with the recommendation of the American Society of Parenteral and Enteral Nutrition, related to specific are for critical patients in hospital contexts without reliable water quality control. $^{2}$

The entire collection was carried out with the help of a systemized observation checklist. The administered dose was used as the error analysis unit. For each dose, only two mutually excluding situations were verified; the dose was administered either correct or incorrectly. In each dose, however, two types of errors could occur, related to the pause and probe management.

To determine how many doses should be observed, the sample was calculated considered the number of doses per month at the unit and the formula was used for sampling calculations in cross-sectional studies with finite populations, using a 95\% confidence level, an a of 0.05 and a critical coefficient of 1.96 , considering that $20 \%$ of the professionals could commit some error, estimated based on hospital records. In view of possible losses, $5 \%$ was added and the amount of doses was rounded off to 350 . Fifty-six nursing technicians were observed who complied with the following criteria: more than six months of experience at the institution; medication administration as a habitual task; and at least one year of experience in intensive care. To reach the 350 doses, each UTI professional was observed, administering at least six doses. The observation took place in March 2010, after receiving approval for the project from the Research Ethics Committee under protocol 004/2010.

The study was based on the error classification used by the National Coordinating Council for Medication Error Reporting Prevention (NCC MERP), a North American entity created in 1995 to maximize rational and safe medication use. ${ }^{10}$ Its objectives are to stimulate medication error reporting and discuss preventive strategies in all phases of the medication system. The errors are characterized according to their potential patient damage and, in this study, the interest was focused on type-B errors. According to the NCC MERP, type-B errors happen but do not affect the patients. One example is the preparation of clarithromycin using distilled water (reconstitution error). The error is detected, the dose is dismissed and a new dose is prepared with the correct solution. As the nursing professionals were directly monitored in this research, observing whether an error was committed or not, the decision was made to intervene whenever a type-B error took place. In these cases, the observed error was registered and the researcher intervened, explaining the mistaken administration and asking the technician to redo the procedure.

The data analysis was based on simple descriptive statistics, which identified the main results for discussion.

\section{RESULTS}

The medication administration was observed in 39 patients hospitalized in March 2010, whose characteristics are shown in table 1 , together with the nutritional therapy characteristics. The majority was elderly, with a slight predominance of female patients, with a high mean number of days in hospital (almost 41 days), and the majority without hydric restriction and without sedation. As regards the EN therapy, all patients received EN through infusion pumps; most patients used nutrition for more than 23 days, and used polyurethane catheters $(82.05 \%)$, predominantly through nasal insertion $(66.67 \%)$, caliber $12 \mathrm{Fr}(84.61 \%)$, gastric location $(100 \%)$ and intermittent infusion (100\%).

The observation of the 350 medication doses administered through tubes resulted in the identification of 53 different drugs. It was verified that $92 \%(n=322)$ doses were in the solid form, predominantly simple pills $(79.19 \%)$, followed by hard gelatin capsules, coated pills, controlled release and only one drug in the pharmaceutical form powder (acetylcysteine). The liquid form with the largest number of doses was syrup (57\%), followed by solutions (32\%) and emulsions (11\%). The prevalent drugs in this research were amiodarone hydrochloride, captopril, amplodipine besylate, acetylcysteine, bamifylline, folic acid, acetylsalicylic aid, bromopride, potassium chloride syrup and rivastigmine chlorhydrate. 
Table 1 - Characteristics of patients and enteral nutrition in ICU. Rio de Janeiro-RJ, 2010 (n=39)

\begin{tabular}{|c|c|c|}
\hline Patient characteristics & $\mathbf{n}$ & $\%$ \\
\hline \multicolumn{3}{|l|}{ Age (years) } \\
\hline$\geq 60$ & 35 & 89.74 \\
\hline$<60$ & 4 & 10.26 \\
\hline \multicolumn{3}{|l|}{ Days of hospitalization } \\
\hline$\geq 24$ & 21 & 53.85 \\
\hline$<24$ & 18 & 46.15 \\
\hline \multicolumn{3}{|l|}{ Sedation } \\
\hline No & 30 & 76.92 \\
\hline \multicolumn{3}{|l|}{ Hydric restriction } \\
\hline No restriction & 32 & 82.05 \\
\hline \multicolumn{3}{|l|}{ Sex } \\
\hline Female & 20 & 51.28 \\
\hline Male & 19 & 48.72 \\
\hline Enteral nutrition characteristics & $\mathbf{N}$ & $\%$ \\
\hline \multicolumn{3}{|l|}{ Tube material } \\
\hline Polyurethane & 39 & 100.00 \\
\hline \multicolumn{3}{|l|}{ Catheter access } \\
\hline Mouth & 7 & 17.95 \\
\hline Nose & 32 & 82.05 \\
\hline \multicolumn{3}{|l|}{ Catheter caliber } \\
\hline $12 \mathrm{Fr}$ & 33 & 84.61 \\
\hline $24 \mathrm{Fr}$ & 6 & 15.39 \\
\hline \multicolumn{3}{|l|}{ Catheter topography } \\
\hline Gastric & 39 & 100.00 \\
\hline \multicolumn{3}{|l|}{ Days of EN } \\
\hline$\geq 23$ & 20 & 51.28 \\
\hline$<23$ & 19 & 48.72 \\
\hline \multicolumn{3}{|l|}{ Indications } \\
\hline Neurologic & 38 & 97.43 \\
\hline Malnutrition & 12 & 30.77 \\
\hline Immunity & 6 & 15.38 \\
\hline \multicolumn{3}{|l|}{ Infusion method } \\
\hline Intermittent & 39 & 100.00 \\
\hline \multicolumn{3}{|l|}{ Speed (ml/hour) } \\
\hline$\geq 55$ & 30 & 76.92 \\
\hline$<55$ & 9 & 23.08 \\
\hline
\end{tabular}

No pause was inserted between the drug administration and the enteral diet infusion in 116 medication doses $(33.14 \%)$ that needed relatively fasting, mainly captopril, warfarin sodium, sodium levothyroxine, digoxin and phenytoin sodium.
Figure 1 shows the list of drugs that required relative fasting and were administered without any pause.

Figure 1 - Drugs administered without enteral diet pause in ICU. Rio de Janeiro-RJ, 2010

\begin{tabular}{|l|c|c|}
\hline \multirow{2}{*}{ Drugs (total doses for each) } & \multicolumn{2}{|c|}{$\begin{array}{c}\text { Doses } \\
\text { without pause }\end{array}$} \\
\cline { 2 - 3 } & $\mathbf{n}$ & $\%$ \\
\hline Warfarin sodium $(\mathrm{n}=39)$ & 37 & 94,87 \\
\hline Captopril $(\mathrm{n}=33)$ & 33 & 100,00 \\
\hline Phenytoin sodium $(\mathrm{n}=14)$ & 7 & 50,00 \\
\hline Sodium levothyroxine $(\mathrm{n}=7)$ & 7 & 100,00 \\
\hline Digoxin $(\mathrm{n}=6)$ & 6 & 100,00 \\
\hline Omeprazole $(\mathrm{n}=6)$ & 6 & 100,00 \\
\hline Iron sulfate $(\mathrm{n}=6)$ & 6 & 100,00 \\
\hline Lactulose $(\mathrm{n}=4)$ & 4 & 100,00 \\
\hline $\begin{array}{l}\text { Levodopa+benserazide } \\
\text { hydrochloride | (n=4) }\end{array}$ & 4 & 100,00 \\
\hline Hydralazine hydrochloride $(\mathrm{n}=3)$ & 3 & 100,00 \\
\hline Nitrofurantoin $(\mathrm{n}=3)$ & 3 & 100,00 \\
\hline
\end{tabular}

\section{Catheter management}

As regards the irrigation of the probes before the drug administration, this did not happen in most cases (94.28\%). On the opposite, no errors were observed with regard to washing the probe with water between one drug and the other and after its administration, nor with regard to the water used, verifying that the nursing team used sterile water in specific probe irrigation recipients.

Table 2 - Distribution of catheter irrigation in medication administration at ICU. Rio de Janeiro-RJ, 2010

\begin{tabular}{lcccc}
\hline & \multicolumn{4}{c}{ Probe irrigation } \\
\cline { 2 - 5 } a & \multicolumn{2}{c}{ yes } & \multicolumn{2}{c}{ no } \\
& $\mathbf{n}$ & $\%$ & $\mathbf{n}$ & $\%$ \\
\hline Before & 20 & 5.71 & 330 & 94.28 \\
During & 350 & 100.00 & - & - \\
After & 350 & 100.00 & - & - \\
\hline
\end{tabular}


The results will be discussed based on the categories studied.

\section{DISCUSSION}

\section{Non-existent pause}

In this category, 116 medication doses were observed (33.14\%), administered without any pause, which meant that the drug was administered at the same time as the enteral diet without its interruption. The most prevalent drugs were captopril, warfarin sodium, levothyroxine sodium, digoxin and phenytoin sodium.

One of the main drawbacks indicated in EN administration concomitantly with medication is the drug-nutrient interaction, which can cause a reduction in the absorption of the drug and/or EN components. ${ }^{11}$

EN and medication formulae are involved in drug-nutrient interactions, mainly of types 1 and 2. The (type 1) "ex vivo" bioactivation reactions frequently happen when pharmaceutical products are directly mixed in EN formulae. As a result, biophysical or biochemical reactions happen and the drug or nutrient may be deactivated. It is highlighted that, in some cases only, the interaction may be confirmed by visual inspection (presence of phases, precipitations).$^{11}$

Type 2 interactions affect the absorption of drugs and nutrients administered through the oral or enteral routes, causing increased or decreased bioavailability. In some cases, the precipitating agents can modify the functions of an enzyme (type A interaction) or the active transportation mechanism (type B interaction) of the nutrient or drug before it reaches the circulation. ${ }^{11}$

On the other hand, the drugs administered through catheters are mostly absorbed by passive diffusion, while the nutrients are absorbed through an active transportation mechanism. Various factors interfere in the absorption and consequently, in the blood concentration of a drug when administered through the enteral route.

The factors related to the drugs are solubility, particle size, pharmaceutical form, gastrointestinal fluid effects, pre-systemic metabolism, pka of the drug ( $\mathrm{pKa}$ is an equilibrium constant), chemical nature, immediate or slow release, enterohepatic circulation. In addition, there are other patientrelated factors, which can be age, fluid intake, intestinal transit time, intestinal microflora, intestinal and liver metabolism, gastrointestinal pathology and gastrointestinal $\mathrm{pH} .{ }^{11}$

In this study, no EN pause was found in any of the captopril doses. The literature estimates that the bioavailability of captopril drops by up to $27 \%$ when this drug is administered together with food, which can thus lead to the reduced therapeutic efficacy and a consequent increase in the pressure levels of patients in need of this drug. ${ }^{11}$

Another drug administered without any EN pause was warfarin sodium. In one study ${ }^{12}$, a reduction in the anticoagulant effect of warfarin sodium was found, caused by the increased absorption of vitamin $\mathrm{K}$ from enteral formulae when the drug is administered together with the $\mathrm{EN}$, and also by the possible union between the warfarin sodium and the protein component of the enteral formulae. ${ }^{12}$

In that sense, patients who receive $\mathrm{EN}$ and who use warfarin sodium, when compared to patients who receive oral feeding, need a dose twice as high to maintain the therapeutic prothrombin time. ${ }^{12}$

The sodium levothyroxine was also administered without any pause and there is evidence that its administration together with EN, mainly with fibers, can reduce its absorption. ${ }^{13}$

In the case of digoxin, the joint administration with EN can provoke a reduction in the drug absorption speed, translated as a reduction of the maximum plasma concentration and delayed in the maximum plasma concentration time, but without affecting the absorption, which remains constant. ${ }^{13}$

Phenytoin sodium was also administered without a pause, and studies show that the absorption of this drug drops as a result of the concomitant administration of EN. ${ }^{14}$

It is proposed that chelation may occur between the phenytoin sodium and divalent cations from the enteral formula, or that bioinactivation and incompatibility occurs between phenytoin sodium and EN. It is also estimated that a change occurs in the gastric and intestinal $\mathrm{pH}$ caused by the EN, with an increased non-absorbable ionized quantity of phenytoin sodium, or the link between phenytoin sodium and the catheter well, a process called adsorption, resulting in a loss of bioavailability. ${ }^{14-15}$

As all patients had a gastric probe, an EN pause before administering drugs can help to 
minimize drug-nutrient interactions and maximize the absorption of drugs that are influenced by the presence of nutrients in the stomach. The literature recommends that, to administer drugs that need relative fasting (so as not to alter the bioavailability), a 30-minute NE pause is due before their administration, as that is sufficient time for the stomach to empty, considering diets infused by a pump at a speed between 50 and $60 \mathrm{ml} /$ hour. $^{7}$

It is recommended that, to optimize the medication administration through catheters, the times should be distinguished from the general intensive care routine, minimizing the number of drugs administered at the same time, guaranteeing greater efficacy of the drugs as, in intensive care, the patients spend long periods receiving EN and drugs.?

The serum bioavailability of the drugs captopril, warfarin sodium, levothyroxine sodium, digoxin and phenytoin sodium may have been reduced, thus reducing their therapeutic efficacy. It is known that the interactions between drugs and nutrients are possibilities, and will not necessarily happen. Similarly, the interaction is unpredictable due to the many variables involved, but it is fundamental for nursing team members to have knowledge about the topic, as that can avoid adverse events based on these situations.

\section{Probe handling}

The irrigation of the tube did not happen before the medication administration in most of the cases $(94.28 \%)$. Washing probes before drug administration is as important as washing them afterwards or in between the drugs, as it is known that many drugs can be incompatible with the EN formulae and that, when in contact with the EN proteins while still in the probe lumen, they can constitute a complex that will obstruct the catheter. ${ }^{16}$

Physiochemical incompatibilities take place when the drug is administered to patients who are receiving EN without previous washing of the probe. When mixed with the EN formula, some drugs provoke a texture change due to the formation of granules or gel. These changes can be caused by different factors in the EN, such as the decreased $\mathrm{pH}$, separation of phases, increased viscosity, increased osmolarity, growth of particles, formation of gel, deterioration of EN, flocculated precipitations and interface incompatibility. ${ }^{17}$

Therefore, washing the tubes before the drug administration is aimed at avoiding physiochemical incompatibilities. One example relates to syrups. In contact with the EN, as their acid $\mathrm{pH}$ corresponds to 4 or less, they are physically incompatible and can thus cause obstruction of the probes. ${ }^{18-19}$

As regards the appropriate fluid to wash the tube, some authors ${ }^{20-21}$ mention filtered water as the best way to preserve tube permeability, but the use of carbonated fluids and fruit juices has also been described in case of probe obstruction. Reference is made to the fact, however, that colabased soft drinks or juices can cause a significant increase in final osmolarity and also enhance the probability of obstruction. ${ }^{20}$

There are strong recommendations that drugs should be prepared in sterile water and that the probes should also be washed in sterile water as, depending on the origin, the drinkable water may contain microorganisms, pesticides, heavy metals and medication residues. The heavy metals present in the water can interact with the surface of the pulverized drugs and produce substances that reduce their bioavailability. ${ }^{2}$

The recommendation to use sterile water for immunodepressed and critical patients, mainly when the drinkable water is not guaranteed, is based on the fact that intensive care patients may have their gastrointestinal barrier at risk, so that exposure to non-sterile solutions needs to be avoided. $^{2}$

The amount of fluid used for probe irrigation was $10 \mathrm{ml}$, but different authors indicate between 10 and $30 \mathrm{ml}^{15-16}$

Although no scientific records were found, another criterion is experienced in practice, which involves using a water volume equivalent to one and a half time the completion volume of the probe. To give an example, polyurethane catheters of caliber $10 \mathrm{~F}$ are completely filled with a volume of $10 \mathrm{ml}$, equivalent to using $15 \mathrm{ml}$ to guarantee the removal of residues. The advantage of washing the tubes using a volume based on the caliber and length of the catheter has the advantage of administering neither more nor less fluid than necessary, but merely sufficient to clean the internal lumen of the tube. Another benefit of this practice is that no positive hydric balance is provoked, which can happen if the catheter is washed with a fixed volume each time a drug is administered. It should be reminded that critical patients suffer from volemia alterations and that its increase raises the cardiac burden, often without any correspondence in the kidney function, which is the case with septic patients. For patients with fluid restrictions, using 5 
$\mathrm{ml}$ of sterile water to irrigate the tubes before, in between and after the medication administration is recommended. ${ }^{2}$

Some drugs observed in this research present a high risk of catheter obstruction, such as simple pills of bamifylline, calcium carbonate, flunarizine, as well as hard gelatin capsules of Tamarine ${ }^{\circledR}$ and zidovudine. For the first three, intense grinding is recommended until turning into a fine powder, as their excipients can obstruct the probe when ground. The Tamarine ${ }^{\circledR}$ and zidovudine capsules are considered hard gelatin capsules of high viscosity, recommending their dilution in at least 20 $\mathrm{ml}$ of water. ${ }^{19}$

The most common effects of the incompatibilities in the loss of medication and/or nutrient absorption due to chelation, changes in the consistency and viscosity of the EN and, the best known effect in nursing, probe obstruction. In a prospective study undertaken at an ICU of a Brazilian university hospital, diet interruption with the consequent repassing of the probe due to obstruction was found as the second main cause of errors. ${ }^{13}$

When probes get obstructed, the workload of the entire team increases, as nursing will have to reinsert a new probe, physicians have to request an x-ray to confirm the position of the tube and the radiology technician has to take an $\mathrm{x}$-ray at the bedside. Probe obstruction not only causes rework for the professionals but also patient damage due to the interruption of the EN for a longer period. Moreover, replacing probes exposes the patients to the risk of esophageal lesion (as an adverse event), nausea, stress, pain and discomfort. In intensive care patients, the damage can be significant, as these patients tend to spend more energy due to situations like infections, besides frequent nutritional depletion, as the metabolic response to stress, known as the acute phase response, promotes intense catabolism and protein mobilization to repair injured tissue and supply energy. ${ }^{22}$

\section{CONCLUSION}

The lack of a pause was verified to promote an appropriate time interval between the diet administration and most drugs requiring relative fasting. It was also observed that the nursing professionals always irrigate the probes in between one drug and the other, as well as at the end of the administration, but do not adopt the same attitude before infusing the drug. In the first case, this practice may have contributed for the patients to have received smaller drug doses than necessary due to drug-nutrient interactions provoked by the absence of relative fasting, which may have reduced the bioavailability of the administered drugs, mainly captopril, warfarin sodium, levothyroxine sodium, digoxin and phenytoin sodium. Similarly, the lack of irrigation of the probes with sterile water before the drug administration may have contributed to the obstruction, although it was impossible to know when and how many times the obstructions took place, due to the lack of records in the files.

Some error barriers could be implanted, such as offering tables of drugs that require relative fasting, as memorizing all the drugs is difficult for nursing, as well as reminders about the advantages of tube washing for nursing, the team and the patient.

The errors found show that, at this ICU, the nursing team has not using appropriate knowledge, although drug management is a usual procedure for this professional category. Improving the knowledge on this theme among the professionals involved in patient care can avoid efficacy and safety problems in pharmacological treatments and prevents disorders for the patient and the nutritional support established. Nurses should be stimulated to discuss the best pharmacological conduct in medication administration with pharmacists, as their different skills should be shared to guarantee safe processes for the patient. The presence of pharmaceutical clinics at the units can enhance the patients' safety, helping to conduct better practices by discussing a more appropriate drug prescription for patients with tubes with the medical team and the correct preparation and administration of these drugs with the nursing team.

\section{REFERENCES}

1. Agência Nacional de Vigilância Sanitária (Brasil). Resolução da diretoria colegiada RDC n. 63, de 6 de julho de 2000. Regulamento técnico para a terapia de Nutrição Enteral. Brasília (DF): MS; 2000.

2. American Society of Parenteral and Enteral Nutrition. Enteral nutrition practice recommendations. J Parenter Enteral Nutr. 2009 Jan-Mar; 33(2):122-67.

3. Schweigert ID, Pletsch MU, Dallepianne LB. Interação medicamento nutriente na prática clínica. Rev Bras Nutr Clin. 2008 Set; 23(1):72-7.

4. Matsuba CST. Obstrução de cateteres nasoenterais em pacientes cardiopatas [dissertação]. São Paulo (SP): Universidade Federal de São Paulo; 2003. 
5. Clopés A, Cardona D, Farré RR, Castro C, Bonal FJ Importancia de las características físico-químicas de los fármacos para su administración por sonda nasoentérica o enterostomía. Farm Hosp. 2008 MarAbr; 22(3):137-43.

6. Telles SCR. Métodos de administração de alimentação por cateteres. In: Associação de Medicina Intensiva Brasileira/Terapia Nutricional em Terapia Intensiva, organizadores. Terapia nutricional no paciente grave. São Paulo (SP): Revinter; 2010.

7. Silva LD. Procedimentos e enfermagem: semiotécnica para o cuidado. Rio de Janeiro (RJ): MEDSI; 2004.

8. Silva LD, Camerini FG. Análise da administração de medicamentos intravenosos em hospital da rede sentinela. Texto Contexto Enferm. 2012 Jul-Set; 21(3):633-41.

9. Secoli SR. Interações medicamentosas: fundamentos para a prática clínica da enfermagem. Rev Esc Enferm USP. 2001 Mar; 35(1):28-34.

10. National Coordinating Council for Medication Error Reporting Prevention [página na Internet]. Rockville (US): NCCMERP; 1998 [acesso 2009 Mar 25]. Disponível em: www.nccmerp.org

11. Reis NT. Nutrição clínica interações: fármaco $x$ fármaco, fármaco $x$ nutriente, nutriente $x$ nutriente, fitoterápico x fármaco. Rio de Janeiro (RJ): Rubio; 2004.

12. Penrod LE, Allen JB, Cabacungan LR. Warfarin resistance and enteral feedings: 2 case reports and a supporting in vitro study. Arch Phys Med Rehabil.
2011 Set; 82(9):1270-3.

13. Schweigert ID, Pletsch MU, Dallepianne LB. Interação medicamento nutriente na prática clínica. Rev Bras Nutr Clin. 2008 Mar; 23(1):72-7.

14. Waitzberg DL. Nutrição oral, enteral e parenteral na prática clínica. $4^{\mathrm{a}}$ ed. São Paulo (SP): Atheneu; 2009.

15. Thomson, FC. Naysmith, MR. Lindsay, A. Managing drug therapy in patients receiving enteral and parenteral nutrition. Hosp Pharmacist. 2010 Jun; 7(6):155-64.

16. Colagiovanni L. Preventing and clearing blocked feeding tubes. Nurs Times Plus. 2010 Jan-Mar; 96(17):3-4.

17. Williams NT. Medication administration through enteral feeding tubes. Am J Health Syst Pharm. 2008 Nov; 65(15):2347-57.

18. Moura MRL, Reyes FG. Interação fármaco-nutriente: uma revisão. Rev Nutr. 2012 Jul-Set; 15(2):223-38.

19. Engle KK, Hannawa TE. Técnicas para administração de medicamentos orais para pacientes críticos recebendo alimentação enteral contínua. Am J Health Syst Pharm. 2009 Abr; 56(14):1441-4.

20. Malagoli BG. Manual farmacoterapêutico para melhoria das práticas em farmácia hospitalar. Belo Horizonte (MG): UFMG, 2009.

21. Katzung BG. Farmacologia básica e clínica. $6^{a}$ ed. Rio de Janeiro (RJ): Guanabara Koogan; 2010.

22. Shils M, Olson JA, Shike M, Ross AC. Tratado de nutrição moderna na saúde e na doença. $9^{\mathrm{a}}$ Ed. São Paulo(SP): Manole; 2002. 